DOI 10.21867/KjK/2016.1.9.

\title{
A GYERMEKVÉDELMI JELZŐRENDSZER KAPCSOLAT-HÁLÓZATI SZEMPONTÚ MEGKÖZELÍTÉSE - ÚJ ÉRTELMEZHETŐSÉGI LEHETŐSÉGEK*
}

\author{
Bertalan Imre ${ }^{1}$
}

A jelen tanulmány középpontjában a gyermekvédelmi jelzőrendszer áll. Az elmúlt évek során számos olyan fontos változás történt - gondoljunk itt akár a jogszabályi kontextus változásaira vagy a gyermekvédelmet érintő illetékességi terület, ezáltal a feladatszervezés módosulásaira - melyek hatást gyakoroltak a gyermekvédelmi jelzörendszer mindennapi feladatellátására.

Jelen írás arra vállalkozik, hogy azonositsa a különbözö kapcsolódási pontokat az eltérö szintü, ám a gyermekvédelemben egyaránt fontos szerepet játszó hivatalok, intézmények, szervezetek és egyéb szereplök között - ezáltal mintegy rendszerezve a közszolgáltatások, közfeladatok széles körének egy szegmensét, továbbá arra, hogy bemutasson egy olyan módszert, melynek alkalmazása a gyermekvédelmi rendszerek új értelmezhetöségi lehetöségét kínálja számunkra.

Véleményünk szerint különös figyelmet kell fordítanunk arra, hogy a feladatellátás jellegéből adódóan igen hangsúlyos szerepet kapnak az interperszonális kapcsolatok és a személyközi nexusokon keresztül történő munkavégzés. A gyermekvédelmi jelzőrendszer mindennapi munkájában részt vevő hatóságok, hivatalok, intézmények és szervezetek valamint legfőképpen azok munkatársai közt feltehetően egy mély informális jellegü hálózat húzódik meg - természetesen az objektíven azonosítható, jogszabályokon alapuló formális hálózat mellett - hiszen a jelzőrendszer valójában nem egymástól független egyének vagy intézmények hálózata, hanem egy dinamikus hálózat, komplex közösségi tevékenység.

Ilyen megközelítésben célszerü a kapcsolati erőforrások dimenzióját bevonni az értelmezésbe, mivel ezen konstruktumok használatával rávilágíthatunk arra, hogy a gyermekvédelmi jelzőrendszer munkatársai és maga a rendszer is egy komplex kapcsolati hálóba ágyazva müködnek. Vizsgálati elrendezésünk alkalmazásával, az összes kapcsolat feltárása révén tulajdonképpen egy nagyméretü közszolgálati szociometriát is kapunk.

A fentiekkel összefüggésben vizsgálódásunk során különösen fontosnak tartottuk, hogy rendszerünk vonatkozásában empirikus úton szerezzünk információt és hogy objektív, megismételhető eljárással szerezzünk adatokat, hiszen ezek a tudományos jellegű vizsgálódás minimális követelményei.

Ennek érdekében elsőként interjúkat folytattunk a gyermekvédelemben nyilvánvalóan érintett és abban aktív szerepet játszó intézmények munkatársaival, így különösen a Szociális Szolgáltatási Központ Gyermekjóléti Szolgálatának kollektívájával. Az interjúk kérdéseinek és fókuszának meghatározása során nagymértékben támaszkodtunk a korábbi évek során szerzett gyakorlati tapasztalatra. Kezdeti hipotézisünk értelmében célunk az volt, hogy megvizsgáljuk a gyermekvédelmi törvény ${ }^{2}$ által explicit módon felsorolt, a gyermekvédelmi

\footnotetext{
A tanulmány a Magyar Tudományos Akadémia és a Debreceni Egyetem Állam- és Jogtudományi Kar közös, MTA-DE Közszolgáltatási Kutatócsoportjának a Területi közszolgáltatások szabályozásai címü projektje keretében készült. A projekt leírására 1.: Horváth M.T.: Szempontok a területi közszolgáltatások regulációs változásainak vizsgálatához. In: HMT (szerk.): Kilengések. Közszolgáltatási változások. Budapest: Dialóg Campus, 2013. 9-25. old.

${ }^{1}$ Bertalan Imre, Hajdúböszörményi Polgármesteri Hivatal, Jogi és Igazgatási Osztály, szociális ügyintéző, kulturális referens

${ }^{2}$ 1997. évi XXXI. törvény a gyermekek védelméről és a gyámügyi igazgatásról.
} 
rendszerhez kapcsolódó feladatot is ellátó szolgáltatók, intézmények, hatóságok - többek között a gyermekjóléti szolgálat, az egészségügyi szolgáltatást nyújtók, a rendőrség, a pártfogó felügyelői szolgálat vagy a munkaügyi hatóság - között meghúzódó kapcsolati hálót.

Az interjúk készítése közben, illetve azok tartalmának vizsgálata során azonban fény derült arra, hogy a lokális gyermekvédelmi jelzőrendszer sokkal kiterjedtebb és valamelyest eltér a jogszabályban meghatározottaktól. Fontosnak tartottuk, hogy a későbbi empirikus kutatásunkat ne csak az igen jelentős mértékben strukturált és kötött intézményi-szervezeti rendszerre alapozzuk, hanem kíséreljük meg feltárni a specifikus helyi relációkat, az intézmények közti lehetséges kapcsolódási pontokat, vagyis azt, ami a valóság.

Ennek érdekében az interjúk szövegét tartalomelemzésnek vetettük alá, mely egy olyan kutatási eszköz és módszer, amelynek segítségével kevésbé strukturált, ám annál szubjektívebb információhoz juthatunk a résztvevők azon kognitív reprezentációját illetően, melyet a lokális gyermekvédelmi jelzőrendszerről alkottak. A strukturálatlan információ, a kötetlen válaszadási forma és a szubjektivitás igen magas fokának köszönhetően, mind kvalitatív, mind kvantitatív szempontból értékelhető adatokhoz jutottunk. ${ }^{3}$ Hangsúlyoznunk kell, hogy a tartalomelemzésnek kontextus érzékenynek kell lennie ${ }^{4}$ és a kérdés-felelet párt olyan egységnek kell tekintenünk, melynek belső szerkezete szignifikánsnak ítélhető.

\section{1. táblázat: A tartalomelemzést követően kirajzolódó intézményi térkép}

\begin{tabular}{|c|l|}
\hline \multicolumn{2}{|c|}{ Intézmény } \\
\hline 1. & Szociális Szolgáltatási Központ Családsegítő Központja \\
\hline 2. & Csillagvár Óvoda \\
\hline 3. & Debreceni Egyetem Gyakorló Óvoda \\
\hline 4. & Szociális Szolgáltatási Központ Gyermekjóléti Szolgálata \\
\hline 5. & Hajdúböszörményi Egységes Pedagógiai Szakszolgálat \\
\hline 6. & Hajdúböszörményi Kincskeresö Óvoda \\
\hline 7. & Hajdúböszörményi Polgármesteri Hivatal Humán és Igazgatási Osztály \\
\hline 8. & Hajdúböszörményi Rendőrkapitányság \\
\hline 9. & Házi Gyermekorvos \\
\hline 10. & $\begin{array}{l}\text { Hajdú-Bihar Megyei Kormányhivatal Hajdúböszörmény Járási Hivatal } \\
\text { Járá Gyámhivatala }\end{array}$ \\
\hline 11. & $\begin{array}{l}\text { Hajdú-Bihar Megyei Kormányhivatal Hajdúböszörmény Járási Hivatal } \\
\text { Járási Népegészségügyi Intézete }\end{array}$ \\
\hline 12. & Jó Pásztor Református Óvoda \\
\hline 13. & Katica Családok Átmeneti Otthona \\
\hline 14. & Klebersberg Intézményfenntartó Központ Hajdúböszörményi Tankerülete \\
\hline 15. & Napsugár Óvoda \\
\hline 16. & Városi Bölcsőde \\
\hline 17. & Városi Főorvos \\
\hline 18. & Védőnői Szolgálat \\
\hline & \\
\hline
\end{tabular}

\footnotetext{
3 Bertalan Imre: A gyermekvédelem lokális rendszerének kapcsolat-hálózati szempontú megközelítése, In:Horváth M. Tamás - Bartha Ildikó (Szerk.): Gyürük és sugarak - Mit nyújt egy magyar város? Budapest Pécs, Dialóg Campus, 2014

${ }^{4}$ Klaus Krippendorf: Tartalomelemzés. In: Sallay Hedvig (szerk.): Módszertani szöveggyüjtemény. Debrecen: Kossuth Egyetemi Kiadó, 1999, 105-153.
} 
$\mathrm{Az}$ 1. táblázat az interjúkat követő tartalomelemzés során kirajzolódó intézmények felsorolását tartalmazza. Látható, hogy ez némileg eltér a gyermekvédelmi törvényben taxatív módon felsorolt, a gyermekvédelmi feladatellátásban részt vevő intézményektől és hatóságoktól, olyannyira, hogy a törvényben szereplő aktorok némelyike még csak említés szintjén sem jelent meg. Ez egybevág kezdeti feltételezéseinkkel, miszerint napjaink közigazgatásában és különösen a gyermekvédelem rendszerében megfigyelhető centralizációs törekvések ellenére ez a kapcsolati háló saját kontextusába ágyazva müködik.

Az empirikus kutatás következő lépéseként szociometriai felmérést készítettünk a tartalomelemzést követően kirajzolódó intézmények bevonásával. Tekintettel arra, hogy jelen cikkünk célja a vizsgálati módszer bemutatása célszerü röviden áttekintenünk a legfontosabb elméleti felvetéseket annak vonatkozásában.

Esetünkben a tartalomelemzést követően megjelenő intézmények vezetöit valamint a rendszer föbb szereplöit véleményvezetőknek is tekintjük, vagyis olyan egyéneknek, akik közvetlen környezetükre hatással vannak, azt befolyásolják. A szakirodalmat tanulmányozva megállapíthatjuk, hogy kapcsolati szempontból a véleményvezetők magas aktivitással, társadalmi elismertséggel jellemezhetők. ${ }^{5}$ Ezen megállapítások is igazolják a feltevésünket, , hogy a gyermekvédelem rendszere újszerủen, a kapcsolat-hálózati megközelítésből eredő faktorok segítségével értelmezhető.

Jól ismert tény, hogy mindenkinek szüksége van másokra céljai elérése érdekében. Az sem igényel különös magyarázatot, hogy az interperszonális kapcsolatok milyen jelentőséggel bírnak, mivel egész életünket interakciókban töltjük másokkal, együtt élünk, tanulunk vagy dolgozunk. Tudjuk, hogy az ember alapvetően társas lény. ${ }^{6}$ Számos okból kifolyólag szükségünk lehet egy csoport, jelen esetben a gyermekvédelmi jelzőrendszer társas kapcsolódásainak térképére - jelen esetben azért, mert az adott struktúrához tartozóknak, az azzal valamilyen kapcsolatban álló egyének számára az is elérhető, ami individuálisan nem lenne az, ${ }^{7}$ vagyis egy valóban funkcionáló struktúra esetünkben megkönnyíti a közösségi szolgáltatáshoz való hozzáférést, teríti annak hatókörét. Ezt a térképet szociogramnak nevezzük, elöállítási módja pedig a szociometria. Mérei szerint az emberi kapcsolatok, tekintet nélkül a megvalósulásuk tartalmára, elsősorban érzelmiek és rokonszenviek. ${ }^{8} \mathrm{~A}$ gondolatrendszer egyik alappillére az a feltevés, hogy ezek megfelelnek az érzelmi vezérlésű spontán kapcsolódásnak és így az adott intézmények - és természetesen azok munkatársai között kialakult és a háttérben meghúzódó hálózatrendszernek. A társas kapcsolatok ezen felmérését, az így kapott válaszok alapján történő hálózatábrázolást és ennek értelmezését nevezzük összességében szociometriának. A szociometriai vizsgálat eredményeként több mutatót is kiszámíthatunk, melyek alapján következtetéseket vonhatunk le az adott csoporttal kapcsolatban.

Tekintsük most át röviden ezeket a mutatókat. A kölcsönösségi index a csoporton belüli kölcsönös kapcsolatok arányát fejezi ki. A sürüségi mutató azt fejezi ki, hogy a társas mező egy-egy szereplőjére hány kölcsönös kapcsolat jut. A kohéziós indexből megállapítható, hogy a szociometriailag lehetséges kapcsolatok hány százaléka realizálódott. A viszonzott kapcsolatok mutatója azt fejezi ki, hogy a deklarált kapcsolatok hány százaléka kölcsönös.

Az adatgyüjtés során 18 kérdésből álló szociometriai felmérőlapot használtunk, mivel ha a szociometriai felmérést kutatási célból alkalmazzuk, célszerübb kötött számú választást alkalmazni. Ezt főként a későbbi értékelési és számítási technikák indokolják. Hangsúlyoznunk kell, hogy ezen vizsgálati módszer nem egyfajta mesterséges szituációban zajlik. Mivel valós, létező közösséget, egy dinamikus és élő hálózatot, rendszert vizsgálunk, a

\footnotetext{
${ }^{5}$ WeImann, Gabriel: The Influentials. People Who In fluence People. New York: State University of New York Press, 1994

${ }^{6}$ Aronson, Elliot: A társas lény, Budapest: Közgazdasági és Jogi Könyvkiadó, 1978.

${ }^{7}$ Coleman, James S.: Foundations of SocialTheory. Cambridge, M.A.: Harvard University Press, 1990.

8 MÉREI Ferenc: Közösségek rejtett hálózata - A szociometriai értelmezés. Budapest: Közgazdasági és Jogi Könyvkiadó, 1971.
} 
vizsgálat is valós helyszíneken, a gyermekvédelmi jelzőrendszer létének helyén, annak valós kontextusában valósult meg.

A kérdöívet, pontosabban annak kérdéseit is a kontextushoz igazítottuk annak érdekében, hogy a válaszadók vonatkozásában az involválódás magasabb fokát érhessük el, ezáltal növelvén eredményeink megbízhatóságát és validitását. A kérdőívben szereplő kérdéseink közt egyaránt szerepeltek rokonszenvi választásokra, a bizalomra, az asszertivitásra, a szakmai aktivitásra és a szakmai kompetenciára vonatkozó kérdések.

Mielőtt rátérünk a gyermekvédelmi jelzőrendszer mögött meghúzódó hálózat ábrázolására, bemutatására és elemzésére, meg kell említenünk, hogy a módszer ilyen irányú alkalmazása újszerünek tekinthető, így minden bizonnyal vannak korlátai. A szociometriát, mint módszert leggyakrabban bizonyos csoportok belső struktúrájának feltárására és annak elemzésére használják, nem kifejezetten a főbb csoportközi - jelen esetben a lokális gyermekvédelmi jelzőrendszer szereplöi közt azonosítható - kapcsolódási pontok felderítésére.

\section{1. ábra: A lokális gyermekvédelmi jelzőrendszer szociogramja}

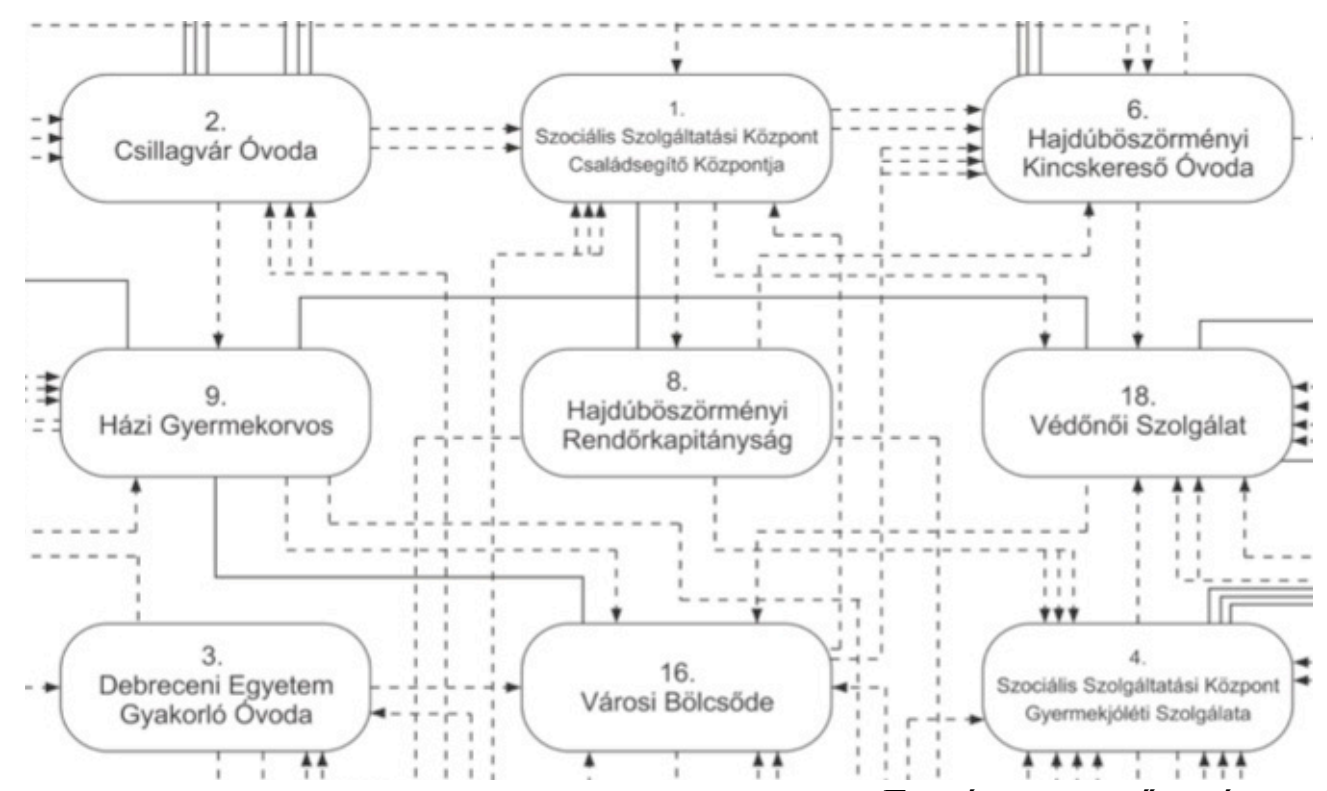

Forrás: a szerzö saját szerkesztése

A gyermekvédelmi jelzőrendszer munkájában részvevő intézmények szociogramjára tekintve rögtön nyilvánvalóvá válik, hogy egy viszonylag egységes, koherens struktúráról beszélhetünk, a periférián elhelyezkedő intézmények száma alacsonynak tekinthető. Megállapíthatjuk azonban, hogy ezen kevésbé centrális helyzetet betöltő intézmények is kapcsolódnak rendszerünkhöz, ezáltal az információáramlást biztosítottnak, míg az ezeken a kapcsolatokon keresztül realizálódó erőforrások eloszlását viszonylag egyenletesnek tekinthetjük.

Szembetűnő lehet néhány intézmény - például a Szociális Szolgáltatási Központ Gyermekjóléti Központja, a Szociális Szolgáltató Központ Családsegítő Központja valamint a Hajdúböszörményi Polgármesteri Hivatal Humán és Igazgatási Osztálya (jelenleg Jogi és Igazgatási Osztály) - centrális helyzete. Ezen intézmények minden bizonnyal a közigazgatásban betöltött funkciójuk eredményeként játszanak jelentős központi szerepet a gyermekvédelem rendszerében.

Mint ahogyan azt korábban is említettük, a szociometriai elemzés során nem csak az adott rendszert, és a rendszer tagjai között megjelenő kapcsolódási pontokat, a kapcsolathálózati struktúrát vagyunk képesek vizuálisan ábrázolni, hanem számos olyan mutatót is 
kiszámíthatunk, melyek segítségével érvényes következtetéseket vonhatunk le a rendszert illetően.

A hajdúböszörményi gyermekvédelmi rendszer kölcsönösségi indexe - vagyis az, hogy a szereplök hány százalékának van kölcsönös kapcsolata - 88 \%. Ez az érték egy átlagos, megfelelő közösségi múlttal rendelkező csoport esetében általában 85-90 \%. A sürüségi mutató, mely azt fejezi ki, hogy a rendszerben egy adott szereplöre hány kölcsönös kapcsolat jut, 1,6-os értéket vett fel esetünkben. Ez az érték így átlagon felülinek tekinthető, mivel ezen faktor sztenderd értéke 0,9 - 1,1 közé esik. Az elemzést követően megállapítottuk, hogy a gyermekvédelem lokális rendszerének vonatkozásában kimagasló értéket vett fel a kohéziós index - melynek használatával azt fejezhetjük ki, hogy a szociometriailag lehetséges kapcsolatok hány százaléka realizálódott - mivel átlagértéknek a 10-13 százalékot tekinthetjük, míg esetünkben ez 27 \%. A viszonzott kapcsolatok mutatója azt fejezi ki, hogy a deklarált kapcsolatok hány százaléka kölcsönös. Esetünkben ezen mutató 36\%-os értéke az optimális övezet határain kívülre esik, mivel az 50-60\%. Feltehetően rendszerünk vonatkozásában ez a mutató azért vett fel kevésbé optimális értéket, mert a rendszernek keretet adó jogszabályok minden bizonnyal meghatároznak egyfajta hierarchiát vagy nyomvonalat, legalábbis hatást gyakorolnak erre.

$\mathrm{Az}$ adatok elemzése és értelmezése révén egyértelműen megállapíthatjuk, hogy valóban létezik az a rejtett és mély hálózat a helyi gyermekvédelmi rendszerben melynek létezését korábban csak sejthettük. Jóllehet jelen tanulmány keretein belül pusztán ezen struktúra létének vizsgálatára térünk ki, megállapíthatjuk, hogy struktúránk megfelel a kapcsolat-hálózati elemzés logikáján alapuló főbb irányelveknek. 